\title{
Active Ingredient Dose
}

National Cancer Institute

\section{Source}

National Cancer Institute. Active Ingredient Dose. NCI Thesaurus. Code C95337.

A quantity of an active ing redient administered, taken, or absorbed at one time. 